DIGITAL COMMONS
@ UNIVERSITY OF SOUTH FLORIDA

Volume 4 | Issue 2

Journal of African Conflicts and

Peace Studies

January 2021

\title{
The Impacts of Political Conflicts in Africa
}

Douglas Kimemia

Virginia Commonwealth Univ, kimemiadk@vcu.edu

Follow this and additional works at: https://digitalcommons.usf.edu/jacaps

Part of the Comparative Politics Commons, and the Other Political Science Commons

\section{Recommended Citation}

Kimemia, Douglas (2021) "The Impacts of Political Conflicts in Africa," Journal of African Conflicts and Peace Studies: Vol. 4: Iss. 2, .

DOI: https://doi.org/10.5038/2325-484X.4.2.1140

Available at: https://digitalcommons.usf.edu/jacaps/vol4/iss2/4

This Article is brought to you for free and open access by the Open Access Journals at Digital Commons @ University of South Florida. It has been accepted for inclusion in Journal of African Conflicts and Peace Studies by an authorized editor of Digital Commons @ University of South Florida. For more information, please contact digitalcommons@usf.edu. 


\section{Virginia Commonwealth University}

\section{Impacts of Political Conflicts in Africa}

"The author states that this manuscript has not been published elsewhere and that it has not been submitted simultaneously for publication elsewhere." 


\section{The Impacts of Political Conflicts in Africa}

Conflicts remain a hallmark of life on the African continent, which is prone to civil conflicts, discord, strife, civil wars, and cases of genocide. For instance, the Armed Conflict Location and Event Data Project (ACLED) reported 520 non-state armed conflicts in 28 different countries between 1989 and 2013, which was higher than any other continent. Unfortunately, 406 of these conflicts occurred in just six countries (Nigeria, Somalia, Sudan, Ethiopia, Kenya, and DRC) (Williams, 2016). The report indicates that the number of conflict fatalities during this period were Sudan $(17,991)$, Nigeria $(15,329)$, DRC $(12,173)$, Somalia $(10,847)$, and Ethiopia $(6,538)$, which accounted for 76.3 percent of the continental total (Williams, 2016). The terror groups such as Al Shabaab and Boko Haram have been on the lead in these countries. While the number of fatalities and other casualties may be accurate and hence likely to differ based on the methodology used to calculate it, these figures are way extraordinary. For instance, the Lacina and Gleditsch methodology dataset reported 419,078 battle deaths occurring in 335 episodes in Africa between 1989 and 2014. On the other hand, Uppsala Conflict Data Programme (UCDP) reported 662,430 civilians' fatalities between 1989 and 2013, which is more than the Lacina and Gleditsch dataset. However, countries like Nigeria, Ethiopia, DRC, and Somalia have the highest number of deaths because of ongoing wars (Williams, 2016).

Unfortunately, at the start of the twenty-first century, Africa is still struggling with new forms of conflicts, even as governments seek desperately to quench the conflicts of the last century. The number of conflicts and deaths continues to rise, while strife and tensions along different social cleavages threaten any chance for political stability and economic progress in some countries. However, since the 1990s, the region has seen a reduction in the prevalence of civil wars even though violent activities have remained on the rise. The reduction of civil wars 
could be attributed to countries with long and devastating histories of conflict settling for peace due to both exogenous and endogenous factors. After many years of civil war and the loss of many lives, countries such as Angola, Mozambique, Sierra Leone, Liberia, and Rwanda are on the road to political stability and economic growth.

Political conflicts in Africa have complex history, multifaceted process, multiple and multidimensional causes and consequences in a complex environment. They cannot be explained or defined by a single variable without reducing them into a simplification of a vast issue and hence a challenge to develop a long-lasting solution. For example, major conflicts lead to instability, damage infrastructure, undermine production industries, and affect the distribution of goods and services. Literature clearly shows that a wide range of social, economic, political, and individual factors are involved or associated with political conflict in Africa. These conflicts are rooted in the complex constructions and conjectures of Africa's political economies, social identities, and cultural ecologies, as configured by specific local, national, regional, and historical experiences, as well as patterns of insertion into and engagement with an everchanging world system (Zeleza, 2008). As such, a careful examination of causes and effects for conflicts in Africa, and of the contributions of social cleavages in this area, is in order

Any genuine study on political conflicts in Africa has to vastly acknowledge its limitations in various levels because the phenomenon of political conflicts is complex, takes different forms, and is contributed to by different factors. As a result, literature in this area has struggled to clearly define the phenomenon leading to no consensus. The literature clearly indicates that it can take many forms, from just political dissent, antagonistic behavior, civil war, regular political protest, violent demonstrations, or the extreme genocide level. It would not be out of order for a scholar to consider acts of vigilantism, collective acts of xenophobic violence, 
etc. Williams (2016) points out that these different forms raise the concern of what the researchers should count or consider as indicators — war, armed conflicts, criminal acts, demonstrations, etc. Based on what is considered as a conflict, the numbers will vary thus leading to different outcomes.

Another challenge is that some acts may go unreported based as a qualifying as a conflict and hence inability to be considered in the analysis. In addition, real-time data is not readily available in some cases unless you rely on the news reports and media outlets, which might be biased and at times limited in their reporting. The other clear issue is how the state apparatus report their data in comparison to other independent agencies. The number always differ leading to either a lack of calculating some cases, especially if you rely on the state apparatus, or double counting especially when you fail to triangulate independent agencies data since some rely on the locals. The local people will differ on how they interpret news or what they saw or did not see. At times, some of those locals may be illiterate or present on the scene thus relying on secondhand information. The reporting of these cases at times is perceived as the way to control the conflict narrative to achieve the desired outcome and support.

Due to the complexity of the phenomenon, ACLED declines to define what a conflict is but leaves the user to define it themselves. However, it defines political violence as "the use of force by a group with a political purpose or motivation" (ACLED, 2017). In order to ensure that there is clarity, the study interprets political conflicts as political events of aggrieved groups, which may be violent or nonviolent, with a focus on civil conflicts, violence against civilians, rioting, and protesting. The non-violent events include forms of protest - such as petitions, parades, displaying symbols or mass demonstrations. These events can be categorized based on the degree of risk involved, the degree to which people are dispersed, and amount of people 
required. The ideal situation would be to embrace all levels of conflict including intra-personal, interpersonal, intergroup, international, regional, and global, but not all those conflicts will necessarily qualify as political conflicts. In addition, there is lack of data that captures all these events therefore; this study relies on the cases reported by ACLED.

While there is ample literature that has focused on the onset of civil or ethnic war in Africa, there seems to be a gap of the most significant factors that lead to political conflicts as manifested by instability at the lower level (Easterly and Levine, 1997; Fearon and Laitin, 2003; Collier and Hoeffler, 2004; Collier and Sambanis, 2005). While in most cases, intervention occurs when a nation has plugged into a civil war, there is a need to understand political conflicts to protect a country from being torn apart, such as in Somalia. The existing literature appear to have omitted some key indicators such as governance and the role of democracy in a country especially Collier's work. In addition, Collier and Heoffler's findings on the causes of civil war have been questioned as unreliable thus leading to unjustifiable conclusions. While most of these studies have focused on civil wars, which, are challenging to define and code, there have been major disagreements on what threshold of violence distinguishes civil war from other forms of internal conflicts. It is also difficult when clearly the beginning and end of civil war. (Sambanis, 2004). A crisis can be categorized as a genocide, war, riot, rebellion, insurgency, terrorism, civil war, or revolution, depending on the coding used (Beenner, 2012).

As a result, this paper is looking beyond causes of civil wars and focusing on political conflicts in general. There are various efforts to compile comprehensive data, the Political Instability Task Force (PITF), Monty Marshall study, and the ECLED. The PITF's dataset provides a range of severe political conflicts and regime crises, such as revolutionary wars, ethnic wars, adverse regime changes, and genocides and politicides (William, 2017). 
This paper will examine the most significant factors that are likely to cause or trigger conflicts in the region using the most current data. This dataset is from the Armed Conflict Location and Event Data Project (ACLED), which includes real-time data on political violence and protest events in over 60 countries (ACLED, 2016). ACLED covers violent activity that occurs both within and outside the context of a civil war, particularly violence against civilians, militia interactions, communal conflict and rioting. ACLED has nine event types including three types of battles, violence against civilians, remote violence, rioting (violent demonstrations), protesting (non-violent demonstrations) and three types of non-violent events. While there are many factors that come into play for any group whether organized or unorganized to be aggrieved by the state, there are some causes that are more noteworthy. Applying a different set of data and indicators, this study aims to generate a deeper understanding of these factors that can drive conflict and of the dynamics that have the potential to result in political stability. This study applies the most recent political events, both violent and nonviolent as opposed to just some few conflicts episodes generated by civil or ethnic wars. This data-set captures more events sufficient to conducting a more in-depth analysis. Therefore, a clear understanding of these factors is important, as it can lead to reducing or eliminating the impact and consequences of violent conflict.

\section{Literature Review}

Conflicts that lead to wars in some cases are products of complex and interconnected causes and contexts, which are informed by the existing political economies and cultural ecologies of a country. When grievances expressed through these conflicts are not addressed, there is a high likelihood of it turning into a war and, at the very worst genocide. Armed conflicts in the continent can be based in the local, national, regional, and global levels. The local relations are 
between individuals and their immediate politico-geographic context; national level focuses on the institutions of state power; regional is focused on geographically coherent, sub-global security complexes that involve the agents of at least two states; and global level is on the deterritorialized networks, structures, processes, institutions or belief systems (Williams, $2017 \mathrm{p}$. 44). These levels are not always mutually exclusive especially when the causes and actors are considered. While understanding these different levels, most scholars would agree that they could not be reduced to one all-encompassing causal explanation. This study identifies multiple causes.

\section{Theoretical Framework}

A study of the causes of conflict requires different theoretical perspectives, which examine how political, economic, social and cultural factors cause and sustain war and conflict, within and between, states and societies in Africa. Motivation or opportunity literature examines the reasons rebel groups choose to engage in armed conflict (Collier and Hoeffler, 1998; Wilmer and Cederman, 2009). According to the inherency theory, human beings are naturally disposed to violence. Even though human beings may restrain themselves based on the prevailing circumstances, when there are benefits to be accrued from engaging in a conflict, they will likely give in. Benefits can be intended or unintended, and can accrue to a narrow or to a large section of the population. Those engaging in conflicts are not expected to be rational, act rationally, or rather accrue any tangible benefits in most cases. The benefit derived might be psychic or emotional, which can be a feeling derived by even with those aggrieving them. Incurring a loss to the other party might be enough reason for this disposition to be provoked. Therefore, people ought to be deterred from engaging in violence through establishing effective institutions. 
On the other hand, economic theories of civil violence developed by Collier and Hoeffler (2000), and by Fearon and Laitin (2003), argue that war is an outcome of an expected utility calculation. War, in particular, is assumed to generate both private and public gains and losses that are unevenly distributed among the parties. Private gains explain why war may be rational for some groups when it is collectively irrational. Often, upward mobility and opportunity are best accessed by an individual through participation in militia forces, whether as a foot soldier or as a leader of the revolution. Potential rebels evaluate their expected gains from war, given their grievances, and compare these expected gains to the expected losses, which include the opportunity-based costs of the foregoing productive economic activity. According to Sambanis (2004), rebellion is, therefore, a rational decision. Further, the financial viability of a rebel organization is determined by whether or not rebellion will be observed, which depends on the material benefits of said rebellion.

Conventional wisdom dictates that poverty increases the risk of conflict in a nation through multiple paths. Limited natural resources lead to competition over farming and grazing land, control over minerals rights, oil reserves, and other resources. According to the theory of relative deprivation developed by Gurr (1970), when there is a gap or discrepancy between what citizens perceive they should have, and what they actually have, this will likely trigger the "frustration-aggression nexus" (Cramer, 2005 p. 17). Aggression or conflict is produced by frustration when one fails to receive one's expected outcome. However, the ensuing conflict must be politicized if it is to appear as collective political violence. The factors significant at the onset of a conflict might not play a significant role in sustaining the conflict. Furthermore, these conflicts are driven by different causal factors. A study done by Fearon and Laitin (2003) found that the number of social factors associated with the onset of civil wars, including both political 
and economic factors, emerged as significant. For example, Collier and Hoeffler (2000) found that economic circumstances such as low income, low growth, and high dependence on natural resources are of critical importance to the onset of civil wars. On the other hand, international aid and money from the diaspora can be used to sustain violent conflict, a condition especially prevalent during the Cold War. Many conflicts were started and sustained depending on the ideological leanings of a given faction. Today, remittances from immigrants in developing nations to rebels have been attributed to financing conflicts or terrorist groups in countries such as Somalia.

Conflicts tear the socio-economic fabric of any society as a country. Conflicts adversely affect a country's economic performance, leaving the nation impoverished. Studies show that countries that are stable and at peace have better economies than countries at war or post-war; their per capita income is more than four times as high as that of post war countries. In addition, countries that are stable have more educated citizens and depend less on foreign aid (Hoeffler, 2008). With the exception of Rwanda, post-war economies are often in worse shape than they were before the war, far from being capable of bringing improvements to political systems. In general, post-war societies are thus less democratic (Collier and Hoeffler, 2007a). However, countries like Liberia and Sierra Leone seems to be challenging this argument as they continue to move towards democracy and stable institutions.

\section{Empirical Literature}

In general, the causes of a conflict can be narrowed down to systemic and proximate factors, or opportunity and grievance. Systemic causes include factors that are ingrained in institutions, whether political, economic, or social. These are the root causes, which include long-standing issues. Systematic causes are underlying structural and deep-rooted factors such as 
economic disparity, historic oppression, political and economic marginalization, and abuses.

Proximate causes are those factors or issues that can further escalate violence. These are factors that contribute to a climate conducive to violent, which in some cases are more visible and symptomatic of a deeper problem. There are also triggering factors that further the escalation of the conflicts.

\section{Table 1.1: Causes and Trigger Factors}

\begin{tabular}{|l|l|}
\hline Systematic or structural causes & $\begin{array}{l}\text { Illegitimate government, lack of political participation, } \\
\text { poor governance, lack of equal economic and social } \\
\text { opportunities, inequitable access to natural resources }\end{array}$ \\
\hline Proximate causes & $\begin{array}{l}\text { uncontrolled security sector, light weapons proliferation, } \\
\text { human rights abuses, the destabilizing role of neighboring } \\
\text { countries, the role of diasporas }\end{array}$ \\
\hline Trigger factors & $\begin{array}{l}\text { elections, arrest / assassination of a key leader or political } \\
\text { figure, drought, the sudden collapse of the local currency, } \\
\text { military coup, rapid change in unemployment, flood, } \\
\text { increased price/scarcity of basic commodities, capital } \\
\text { flight }\end{array}$ \\
\hline
\end{tabular}

Systemic and proximate causes can be categorized as internal or external factors, depending on their origin. Internal factors originate from within the nation, while external factors are mostly influenced by international forces, which are beyond the national borders. External factors include the legacies of Cold War policies, arms flows, and military aid; internal factors include geographical conditions, poverty, militarization, competition for state power, ethnic and religious divisions, and socio-economic inequalities.

Collier and Sambanis (2005) included in their list of reasons a weak government military, social cohesion, general need, extortion of natural resources, low cost of military equipment, and financing of rebels from hostile governments. According to Collier and Sambanis (2005), the financing of rebels creates an opportunity for said rebels to engage in a war. Rebels can be 
motivated by resources that they will receive during and after a war. Financing of rebels can come from the extortion of natural resources available within a nation.

Collier and Hoeffler (2000) found that the presence of natural resources provides easily "lootable" assets for "loot-seeking" rebels or convenient sources of support of "justice-seeking" movements. Lootable resources give insurgents a source of stable income and can help overcome the collective action problem through greed-based motivation by incentives through side payments. Resource conflicts, accelerated by poor economic opportunities and low incomes create an incentive for individuals to choose violence. Akokpari (2008) concludes that Africa's conflicts boil down to the "struggle over state and resources" (p. 103). In reality, however, the struggle is more than just about resources, although the competition for the control of resources is prominent. Collier and Hoeffler (2004) point out that the existence of natural resources in a country provides an opportunity for rebellion since, if victory is achieved by one side, these resources can be used to finance the war and increase the payoff. Access to natural resources, such as oil and minerals, can lead rebels to obstruct the further extraction of natural resources as the likelihood of secessionist movements increases. Cutting rebels' access to raw materials can undermine their military capability, but they may have other ways of financing their operations.

Fearon and Laitin's (2003) insurgency model maintains that wars break out when government forces are weak and when mountainous terrain allows rebels to hide and retreat. Feasibility literature focuses on the favorable geographic conditions for the insurgency, the idea being that, respectively, geography and demographics lower the cost of financing rebel military forces. The benefits of war can exceed its costs, especially when at least one country, group or individual involved is relatively immune to these costs. Those who benefit from violence may find it relatively easy to avoid the alternative, though peacetime livelihoods rarely offer the same 
benefits and security as does membership in an armed force, be it government, rebel, or criminal, despite the costs of fighting and trading. This may explain patterns and persistence of conflict. Recruits must be paid, and their cost may be related to the income foregone by enlisting as a rebel. Rebellions may occur when foregone income is unusually low. When rebels are motivated by the greed or viability model, they are more interested in surviving rather than victory or political change, a condition which leads to the potential for a very long war. For example, the conflicts in the eastern DRC, which are mainly over the control of natural resources, have extended for a long time as new and different rebel groups continue to crop up.

A weak government characterized by weak institutions is likely to make it possible for conflict onset and sustenance. A weak government is likely to have a weak military, one that is ill-prepared to handle rebellion. Rebels are likely to calculate their chances of overcoming in the struggle as being fairly high. The struggle over power and resources becomes dangerous when coupled with weak government and military capability. State power is desirable as it determines who controls both the resources and the nation's purse strings, thus intensifying competition. Unequal access to state power inevitably creates conflict, as those in power attempt to consolidate it and those outside the circle fight to get in. Socializing the means of production means that the state will provide the main channel to the accumulation of personal wealth and securing privileged positions. This causes a brutal competition for power and position, in which groups and individuals feel that they must win at any cost to society or individual life.

Weak states face a diverse range of threats, both internal, such as from armed factions and minority rebellions, and external, such as from regional actors or spillover fighting from neighboring states. Weak governments are characterized by weak political institutions. When a government is weak, rebels can expect to win. Several studies find that partial democracies are 
more prone to civil wars than are full democracies or autocracies (Sambanis, 2001; ReynalQuerol, 2002). Montalvo and Reynal-Querol (2005) examined whether the type of democracy in a nation can explain the presence of civil war in some countries, finding a negative relationship between the inclusiveness of political institutions and the incidence of civil wars. ReynalQuerol's results on the relationship between democracy and civil wars parallel the literature on the relationship between democracy and growth. Glaeser et al (2004) found that political institutions have weak effects on growth. A country's particular form of democracy, rather than democracy per se, has important consequences for the adoption of the specific structural policies that can promote growth. States that transformed from autocracy to multi-party democracy were twice as likely to experience wars in the following decade than states that remained autocratic (Liphart, 1999). During processes of political liberalization, new elites and old ruling groups, fighting over public support, often resort to nationalist appeals. It is difficult for an already weakened state not to further fragment under the strain of liberalization, especially with the existence of winner-take-all approaches to democracy. Severe pressures are compounded by powerful remnants of the old order, such as military and internal security systems, which are often responsible for keeping weak states together by force. Especially when ethnicity is an important factor in party affiliation, losing an election can mean exclusion from power for an entire ethnic group, followed by discrimination and even repression. Weak states undermine their own economic growth and political stability. Democracy is difficult or impossible to foster when a state is unable or unwilling to provide at least the basic goods expected by citizens. The territorial integrity of weak states is threatened, as they are likely to have porous borders, with huge black markets in both people and goods. Corruption is rife throughout the state, with many 
institutions, therefore, functioning sporadically, leaving much of the population dependent on personal networks and clientele ties in order to survive and try to prosper (Kimemia, 2016).

Economy indicators include a country GDP, economic effectiveness index, and corruption perception index. Gross Domestic Product is an economic indicator of how a country is performing economically. It is measured by a country GDP growth rate derived from World Bank. The GDP index is averaged to have a single index. The assumption is that citizens are less likely to engage in political conflicts if they have a stable country economically. If there is enough wealth in the country, a government will collect enough taxes to pay for goods and provide services, especially to the poor. In such a country, the middle class will be strong, as they have jobs to provide required resources to support themselves.

Corruption hampers delivery services in the public sector and diverts public resources away from intended goals. When public funds are embezzled and public officials abuse, their power for personal gain, it affects the most vulnerable members of the society. This lack of or poor services due to corruption will increase the chances of political conflicts as citizens demand transparent and accountable government. The corruption index is composed derived by averaging the Corruption Perception Index (CPI) collected by Transparency International. Economic effectiveness score or index (systematic peace.org) is composed of an average of Gross Domestic Product per Capita from 2007-2013.

\section{H1: A country with a growing economy is likely to have less political conflict.}

Unequal power distribution may lead to discrimination against certain communities. Groups that are politically excluded look for ways to access power, and depending on what is at stake, these groups may perpetrate violent acts. Political discrimination captures expressed instances of group-based grievances. It is also, essentially, one part of a broader intergroup 
conflict of which violence and civil war constitute other elements. In conflicts that are fought in the name of discriminated groups, rebel movements are composed of mobilized and militarized organizations that challenge the government (Cederman et al., 2010). In the recent past, the African continent has faced conflicts driven by the underrepresentation of groups within the governing coalition. For instance, the genocide in Rwanda and the armed conflict in Burundi in the early 1990s have been attributed to the underrepresentation of Hutus who were the majority in a country with a government led by minority Tutsi. Studies conducted by Gurr (1993b) indicate that political discrimination has an impact on the likelihood of armed rebellion and secession. Cederman et al (2010) found that excluded groups across all income levels, when compared with included groups that enjoy representation at the center of government, are three times more likely to initiate conflict against the state. Groups experience intense pressure to consolidate power in case there is a serious challenge. Fear of eventually losing power can lead to a rapid effort to expand resources, often illicitly and extra-judiciously, under the control of the $\operatorname{group}(\mathrm{s})$ in authority.

Another source of rebel military opportunity is social cohesion. Ethnic and religious diversity within a country tends to reduce the rebels' ability to function. An ethnically diverse society may reduce the opportunity for rebellion by limiting the recruitment pool. Some studies analyze conflicts between ethnic groups under conditions of state failure, thus making the absence of the state the very core of the causal argument. Others assume that the state is ethnically neutral and try to relate ethno-demographic measures such as fractionalization and polarization to civil war. Countries with larger populations have a greater likelihood of experiencing conflicts. Larger populations also increase the pool of potential combatants from which rebel leaders may draw. States with larger populations are inherently weaker, increasing 
the likelihood of civil war. With regard to state strength, larger populations make it harder and more costly for the government to track activities at the local level. Recruitment is more difficult for smaller groups than for larger ones.

Social structure theory argues that certain societal arrangements increase the likelihood that some kind of spark will ignite into armed conflict. At the same time, certain kinds of structures lower the costs associated with civil war. Montalvo and Reynal-Querol (2005) show that ethnic polarization explains the likelihood of conflicts and civil wars. Ethnicity has been accused of being a means through which, by utilizing political mass mobilization, conflicts are conducted. An ethnically diverse society has a higher probability of ethnic conflicts, which may lead, in the worst of cases to a civil war. The ensuing security dilemma creates a situation in which two or more groups that do not trust and may even fear and hate one another and do not believe that institutional constraints will protect them are likely to attack first, believing that doing so is necessary to protect themselves.

Collier and Hoeffler (2004) argue that countries in which one finds "ethnic dominance"-meaning that a single ethnic group makes up 45 to 90 percent of the populationare more prone to major civil conflicts than either those highly homogeneous countries where one group forms more than 90 percent of the population or those highly fractionalized countries where each group comprises less than 45 percent of the population. Bates (2002), by contrast, studied the relationship between ethnicity, economic modernization, political participation, and civil violence in 46 African countries during the period 1970-1995 and found that ethnic dominance increases the risk of war, while diversity may reduce that risk.

A blend of compact ethnic homelands with significant dispersion may actually be the most volatile combination. The extent of past internal ethnic migration can only be captured by 
time-sensitive, local-level census figures associated with what Fearon and Laitin (2011) term 'sons of the soil' conflict that threaten the very base of social order and cohesion in multi-ethnic societies. This is basically a response by a primary ethnic group to secondary ethnic minorities within what it perceives as 'its' territory. Thus, a minority at the state level becomes a majority at the provincial or local level, and its response to diversity is shaped by patterns of ethnic settlement. Fearon and Laitin (2011) remark that the 'sons of the soil' dynamic takes the form of settlers encroaching on indigenous land, which may provoke a violent response, leading to civil violence.

The social cohesion indicators include ethnic fractionalization, religious fractionalization, religious diversity, and group grievance. Ethnic fractionalization is the probability that two randomly selected people will not belong to the same ethnic group (Alesina et al., 2003). The larger the number of ethnic groups in a society, the higher the level of fractionalization. The index of fractionalization, measured along ethnolinguistic and religious lines, is a proxy for the number of competing groups in a society. Easterly and Levine (1997) found that fractionalization of society along ethnic lines is associated with low schooling, political instability, underdeveloped financial institutions, and poor institutional quality. When countries are highly fractionalized along ethnic, religious, and regional lines they are likely to be prone to the frequent breakdown of law and order. Ethno-religious cleavages continue to challenge effective governance and, in many cases, are used to incite people into conflicts, thus creating political instability. A higher measure of religious fractionalization can be a sign of a more tolerant and democratic form of government. The Religious Diversity Index (RDI) developed by Pew Research Foundation looks at the percentage of each country's population that belongs to eight major religious groups, as of 2010. 
Group grievance (developed by Peace Fund as an indicator of Fragile States Index) focuses on the tension and violence that exists between different groups and the state's ability to provide security, which can result in fear and continued violence. Increased group grievance will lead to an increase in the number of political conflicts. This index is a composite of nine years' average (2006-2013).

\section{H2: A country with a less social tension is likely to have less political conflict.}

Those who look at the conflict through a Relative Deprivation Perspective claim that identity is not the cause of the identity conflict, however, religion "supplies the fault line along which intergroup identity and resource competition occur" (Agbiboa, 2013). When applied to conflict the Relative Deprivation Theory, which states that conflict, arises when the feeling that people have less than they should have and the tendency is to fight those who may be perceived to take their share dissatisfies people.

There are different factors that are likely to lead to grievances such as colonial legacy, ethnic or religious hatred, political repression, political exclusion, and economic inequality (Collier and Sambanis, 2005). There is no doubt that some of the conflicts in the region can find their origins in the colonial past. Studies and experience indicate that the majority of all African internal conflicts have their roots in colonialism and the subsequent process of de-colonization and state formation. Henderson (1991) found that colonial legacy was more "strongly associated with the probability of civil war and that the non-French colonies were more likely to experience civil wars (p.62).

State fragility determines the ability of a country to manage conflict; make and implement public policy, and deliver essential services. Fragility also focuses on a country's resilience in maintaining system coherence, cohesion, and quality of life. A country with high 
stability to manage conflict has a lower chance of political conflict. While a country with a significant amount of instability in one region may be perceived as itself unstable overall, the rest of the country may be stable. Citizens from those unstable areas are likely to be more aggrieved as their rights and liberties are ignored and are likely to fight for more political participation and inclusion in the political decision-making process.

State legitimacy variable measures factors related to public corruption, political participation, government effectiveness, and protests and demonstration. According to Fund for Peace (2016), corruption and a lack of representativeness in the government directly undermine the public trust. This index is composed of pressures related to government effectiveness, the electoral process, protests, and demonstration. This index is an indicator of a country's fragility, which is an average of nine years (2006-2013).

In addition, legitimacy index measures state fragility. This is an indicator used by Systematic Peace organization to measure state fragility. Legitimacy score is composed of security Legitimacy + Political Legitimacy + Economic Legitimacy + Social Legitimacy (12 points possible). The points are then averaged from 1995-2012 to have one composite score. Political legitimacy developed by Ted Robert Gurr, Monty G. Marshall, and Victor Asal, is composed of adding four indicators that were used to determine the Regime/Governance Inclusion score: Factionalism; Ethnic Group Political Discrimination against 5\% or more of the population, Political Salience of Elite Ethnicity, and Polity Fragmentation.

Political effectiveness (Poleff) measures the regime/governance stability. There are three indicators used to calculate the stability index: Regime Durability; current leaders Years in Office (leadership duration); and a total number of Coup Events developed by Monty G. Marshall and Donna Ramsey Marshall, (Systematic Peace, 2017). 


\section{H3: A politically stable country is likely to have less political conflict.}

Political indicators include political rights, civil liberties, state legitimacy, political effectiveness, and fragility. The political rights and civil liberties ensure that citizens have their rights enshrined and protected by the constitution. Political rights and civil liberties in Africa have improved over the last two decades, as democracy has continued to be strengthened in most countries. Since the 1990s, the continent has increased political reforms, with many countries conducting free and fair elections. Most of these elections have led to a change of regimes and administrations. There has been more political participation and respect of human rights. The data was collected from Freedom House, which is an organization that promotes democratic change with a focus on political rights and civil liberties. The Civil Liberties index $(1=\mathrm{BEST}, 7$ =WORST $)$ and Political Rights index $(1=$ BEST, 7 = WORST $)$ were devised from averaging the results from 1990 to 2013.

The next three variables (DEMO, AUTO, and POLITY) are composed of data collected by POLITY IV PROJECT (Marshall, 2016). The DEMOC and AUTO are two indicators of democracy and autocracy in a country. The democracy indicator is an additive eleven-point scale (0-10). It is composed of competitiveness of Executive Recruitment, the openness of Executive Recruitment, the constraint of Chief Executive, and competitiveness of political participation. AUTOC is derived from coding of the competitiveness of political participation, the regulation of participation, the openness and competitiveness of executive recruitment, and constraints on the chief executive.

Polity Score (POLIaverage) is used as an indicator of democracy in a country. It is computed by subtracting the AUTO score from the DEMO score; the resulting unified polity scale ranges from +10 (strongly democratic) to -10 (strongly autocratic). The POLITY variable 
provides a convenient avenue for examining general regime effects in analyses but researchers should note that the middle of the implied POLITY "spectrum" is somewhat muddled in terms of the original theory, masking various combinations of DEMO and AUTO scores with the same POLITY score.

\section{H4: A country with strong democracy has a lower likelihood of political conflicts.}

The four hypotheses were tested using a multilinear regression to find out the most significant variables in predicting a likelihood of political conflicts. The data was cleaned to make sure any missing cases were left out.

\section{Methodology and Findings}

The paper analyzes secondary data collected and prepared by database of credible organizations, which are all western-based. It would be then to acknowledge a possibility of biasness in data composition though none identified here. In a continent where there are only 54 countries, it would be prudent to include all of them for analysis. However, only 49 countries were considered as the rest were omitted due to lack of data. In order to determine the most significant factors, violent and nonviolent events from 1997-2014 for each country are averaged together to be the dependent variable. According to available ACLED data, there was a total of 94,028 violent events from 1997-2014 in all these countries. These data include both violent and non-violent actions.

As the following graph shows, violent events have been on a sharp rise from 2010 to 2014 after showing some signs of plateauing in the last decade. This sharp increase can be attributed to aggressive covering and reporting by media, civil society, and easier access into some of these affected places. Nevertheless, this rise is not widespread, as can be attributed to the Arab uprising, which happened in the North African countries such as Libya, Tunisia, and 
Egypt during this period. While those countries had seen some shares of violent activities before the Arab uprising, what occurred was unprecedented, especially in Libya and Egypt. These conflicts have remained a common phenomenon in Libya and Egypt to some extent. Due to the political vacuum created following the fall of Gadhafi's regime, terror groups such as ISIS have moved in the remote regions to occupy and control oil fields. This has destabilized the newly formed governments in Libya. With the exception of the latest sharp rise, political violence and protest rates have been relatively stable.

Graph 1.1: Violent and Nonviolent Events

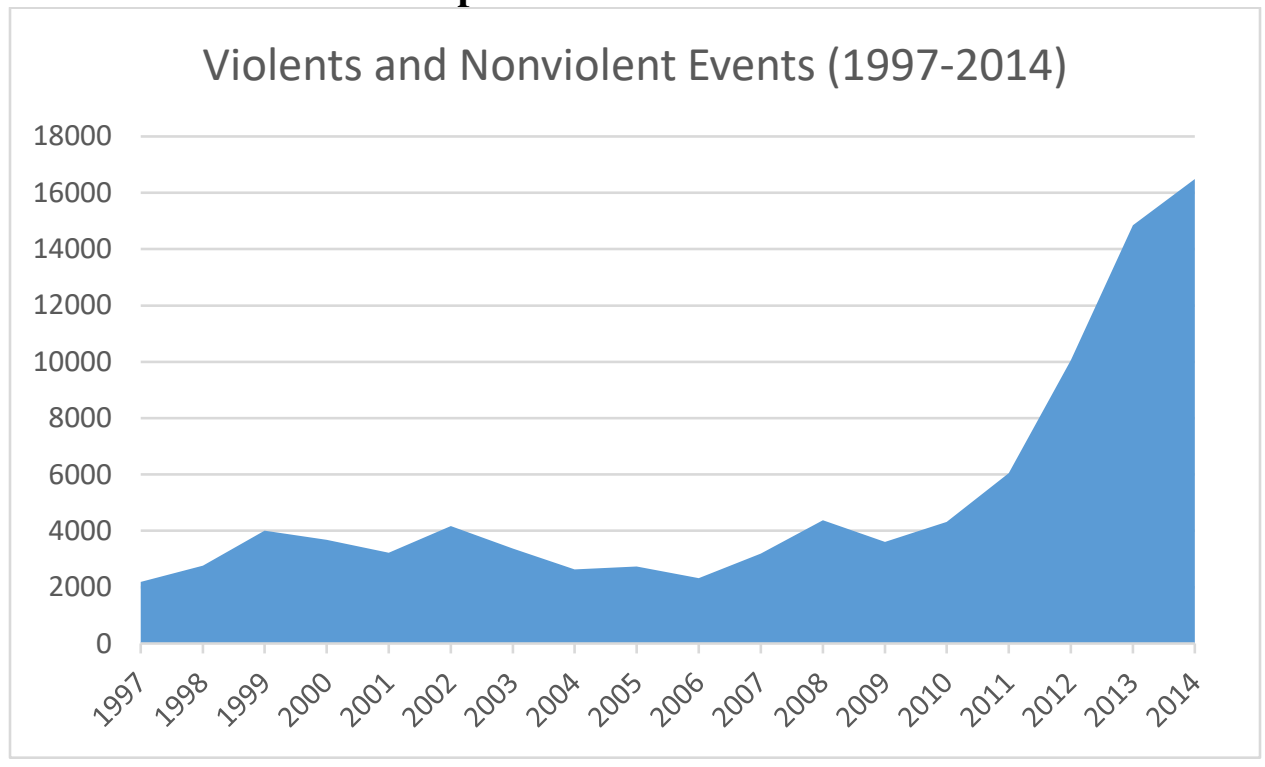

The descriptive analysis of the variables in Table 1.1 indicates that on average, there were 138 political conflicts per year for all the 49 countries. The average number is higher for some countries that experienced a limited number of conflicts due to their political stability. For example, countries such as Benin, Botswana, Malawi, Swaziland, Mauritania, Morocco, and Togo had less than 10 political conflicts on average per year. However, countries such as Algeria, Burundi, D. R. of Congo, Ethiopia, Kenya, Nigeria, Sudan, and Uganda indicated a higher number of cases in general due to their perennial situation. While Angola had many 
political conflicts in the early 1990s and early 2000s, the political conflicts have significantly decreased in the last decade. Other countries such as Libya, Mali, Egypt, and Tunisia have experienced high number conflicts in the last few years, even though they had lower cases before.

The GDP on average was 4.6 percent, though Somalia did not record any growth either negative or positive. This growth is in line with the progress being achieved in the region. Even with the economic depression that occurred both in North America and Europe, African countries enjoyed continued growth, making the region one of the fastest-growing economies. However, that is not the case for all countries, as some are seeing their economy slow due to oil prices going down and continued political conflicts. For instance, Nigeria's economy is not dealing with low oil prices but with Boko Haram terror ground and internal conflicts.

On average, the perception of corruption remains high as it was only 31 percent which is on the lower side as 100 percent denotes countries that are less corrupt. This means the majority of African countries are still struggling with corruption. Corruption affects development, as foreign investors are less likely to invest in countries, which are highly corrupt. Corruption also leads to public mistrust of their government and demoralized government workers.

Both political rights and civil liberties, which indicated the level of political space, were all below five. This number indicates that the majority of these countries have a poor record in both areas, and there is minimal political freedom and civic engagement. Recently, some countries such as Uganda and Ethiopia have been on the record for suppressing free speech, media freedom and freedom of association. Some of these countries have had increased excessive use of force and intimidation on protestors or citizens using social media to highlight government failures. However, since the beginning of 2010, the continent has indicated clear 
signs of increased political reforms. While not all countries have a poor record, there is a need for African countries to continue opening up for political participation.

\section{Multilinear Regression Analysis}

All the predicting variables were tested for multicollinearity, which led to the elimination of the highly correlated. Several of the predicting variables had the lowest variance of inflation factor (VIF) of 1. The variables with low correlation included economic effectiveness, GDP, and Religious Diversity. The moderately correlated variables were: Corruption Perception Index (CPI), Political Effectiveness, Group Grievance, Religion Fractionalization, Ethnic Fractionalization, state legitimacy, and legitimacy. Those variables that were highly correlated included democracy, autocracy, and civil liberties. However, civil liberties and polity variables were retained after showing a drop in VIF following the elimination of Political Rights, DEMOC and AUTOC variables due to their high correlation.

Correlation and multiple regression analyses were conducted to examine the relationship between political conflicts and various potential predicting variables. The multiple regression model with all seven predictors produced $\mathrm{R} 2=.408, \mathrm{~F}(7,41)=4.031, \mathrm{p}<.005$. As can be seen in Table 1.2 below, the model can explain 41 percent of the variance. The adjusted R-squared indicates that 31 percent of the variability of political conflicts is accounted for by the model, even after taking into account the number of variables in the model. After testing the significant predictors, the F-test indicated that the overall model as significant at 95 percent confidence level.

The predicting variables were significant at a different confidence level. These variables included GDP, Religious Diversity, CPI, POLEffect, Legitimacy, Polity, and Ethnic fractionalization. The variables POLILEGIT, State Legitimacy, Religion Fractionalization, 
EconEff, Group Grievance and Political Rights were dropped from the entire model for lack of significance.

As can be seen in Table 1.3 below, the GDP had significant negative (-24.546) unstandardized coefficients. This indicates that countries that have declining economies are likely to see an increase in the number of political conflicts. Specifically, for every onepercentage increase in GDP, there would be less 25 political violence while controlling other independent variables in the model. The model also suggests that corruption is negatively correlated with the number of political conflicts. Specifically, one percentage reduction of corruption would lead to a reduction of 7 political conflicts at 95 percent confidence level. Political effectiveness had a significant negative correlation $(\mathrm{p}<90)$ and indicated that perception of increased government performance would result in less than 73 events. Ethnic fractionalization had a significant negative correlation $(\mathrm{p}<90)$ and indicated the highest drop of conflicts among the seven predictors. For every one percentage change in the level of ethnic fractionalization, the political conflicts will go down by 240 . Religious fractionalization was not that significant and indicated a negative correlation. Increased religious diversity is likely to see a reduction of conflicts by almost 17 events.

Legitimacy and Polity indicators had a positive correlation $(\mathrm{p}<99 ; \mathrm{p}<95)$ to the conflicts. Similarly, for every one unit of the negative perception of state legitimacy, there is an increase of 49 political conflicts in a country. For every one index towards autocracy or polity, there will be an increase of 15 political conflicts.

\section{Discussion and Conclusion}

Political conflicts can be characterized by "major tactical and strategic use of organized violence in an attempt by political and military elites to gain a favorable outcome in an ongoing, group 
conflict interaction process" (Marshall, Robert, and Harff, 2012 p.4). Some conflicts are of smaller magnitude and take a shorter duration when compared to those that later become a longlasting civil war or genocide. The African continent has experienced all these sorts of conflicts, which can be attributed to the political instability of the region. The study clearly indicates that social, economic, and political factors are significantly correlated to conflicts in Africa.

This study reveals that economic growth is important for a stable country. Countries with well-performing economies, as indicated by high performing GDPs and less corruption, are likely to have less political conflict. People are less likely to engage in protest as they have access to jobs and can sustain themselves. However, while people might be satisfied by earning an income, they will later engage in a more nonviolent protests or demonstrations in struggle for higher hierarchy of needs like job security and self-actualization. Job creation is also key, as investors, including international, are attracted to a country where there is certainty and stability. They also prefer countries where there is no corruption or it is at the lowest. In countries where corruption is high, investors are required to incur extra costs to run their business due to rentseeking culture and bureaucratic corruption. While corruption within a government is not a systematic facto,r it is enough to trigger violence if it's not addressed. The study found that corruption was significant, and failure to address it will lead to a government that is ineffective and inefficient in distributing the public services to its citizens. However, any benefits acquired from economic progress has to be passed to the citizens. Countries such as Botswana and Benin were among the countries with the lowest number of political conflicts to also record a consistent economic growth. Any wealth created in these nations is distributed to the citizens, whether in terms of improving infrastructure or service provision. 
The strength of a government is depicted by the ability to address the grievances of its citizens and explains why some countries have a higher level of political conflicts than others. Failure to address any conflict in a manner perceived as respecting citizens' rights will lead to more conflicts. Violence begets violence. State intimidation and human rights abuse are a trigger of violence. Political effectiveness which measures government stability, was significant in reducing the number of political conflicts. This means that any regime has leadership turnover as leaders who overstay are likely to encourage citizens to force them out of office or the military to engage in a coup. For example, in Mali, the military intervened in 2010 and overthrew the government after Islamic militants, joined by members of the Tuareg ethnic community, invaded the north. The Malian military felt obliged to take charge and act in the interests of the nation due to what was perceived as political ineffectiveness (Kimemia, 2016).

Weak or fragile states face a diverse range of threats, both internal, such as from armed factions and minority rebellions, and external such as from regional actors or spillover fighting from neighboring states. This study concludes that a country with stronger institutions that are crucial in managing group grievance and allow political participation has minimal political conflicts. A country that is accountable and transparent is likely to see few political conflicts. Likewise, citizens who trust their government to address their grievances in a transparent way are likely to have less motivation to engage in a political conflict.

While Political Rights and Civil Liberties were not considered significant, Polity index, which is another measure of a country's democracy level, was significant. The outcome is supported by several studies that concluded that partial democracies are more prone to civil wars than full democracies or autocracies (Sambanis, 2001; Reynal-Querol, 2002). A country's particular form of democracy, rather than democracy per se, has important consequences for the 
adoption of the specific structural policies that can promote growth. A country that is considered as autocratic with suppression of political rights and civil liberties, positions itself to see more political conflicts as citizens' way of fighting for increased political participation and freedoms.

The state of fragility in a country, as indicated by legitimacy index, is very important. Studies conducted by Gurr (1993b) indicate that political discrimination has an impact on the likelihood of armed rebellion and secession. Cederman et al (2010) found that excluded groups across all income levels, when compared with included groups that enjoy representation at the center of government, are three times more likely to initiate conflict against the state.

Social cohesion is key in making sure a country is stable. The social tension created by different cleavages such as ethnic and religious divisions are likely to trigger political conflicts. While ethnicity is an endogenous factor, religious diversity is more exogenous in itself. However, these identity groups seek different things such as autonomy, recognition, and inclusion in the decision-making process (Kimemia, 2016). The political elites have to ensure that they do not manipulate these groups for support or incite them to fight each other. Countries with a high level of ethnic and linguistic fractionalization can be considered as more vulnerable or fragile to high chances of ethnic conflicts. A higher measure of religious fractionalization can be a sign of a more tolerant and democratic form of government. While ethnic and linguistic fractionalization are associated with negative outcomes in terms of quality of government, religious fractionalization is not; in fact, if anything, this measure displays a positive correlation with measures of good governance (Alesina et al., 2003).

There's clear evidence that social vulnerability has a significant impact on political, as well as economic vulnerability. Ethnic polarization is key in most of these African countries in ensuring that perception of relative deprivation does not trigger ethnic conflicts. While social 
cleavages such as ethnicity and religion are more endogenous, how a state handles these groups is important. Highly fractionalized countries have to ensure that there are stable institutions that enjoy popular legitimacy, exemplified by competitive elections and fair representation.

Recently, the power-sharing approach as a form of mediation and dealing with conflicts has been tried in various countries, and relative successes were recorded in Liberia (2003), Cote d'Ivoire (2007), Sudan (2005), Kenya (2008), Zimbabwe (2009), and Mali (2015). However, this approach has been criticized as ineffective, too inclusive and too exclusionary, and incentivizing violence (Williams, 2017). For the rebels to turn around and give up on conflict there has to be a high of degree of trust and a sense of fairness in the future policies. In addition, there has to be a sense of satisfaction in order to be fully committed to the peace process and conflict resolution.

This study used a different measure of conflicts and real-time data and found some of the most significant factors in explaining political conflicts in the region. The study aligns with others that have also tested these indicators and concluded that they are important in African countries in order to establish stability. African countries need more economic reforms and policies that are fair and just to all the different groups. The countries should ensure that economic marginalization is a thing of the past. These identity groups should feel economically empowered and in control of their resources. The political institutions should be strengthened to make sure that there is smooth power transition and reduce chances of leadership vacuum. More political participation and increased civic engagement should be at the central of any regime. A more participatory democracy will reduce tensions and government mistrust. 


\section{References}

Africa Development Bank (2009). Africa development report 2008/2009. Conflict resolution, peace and reconstruction in Africa. The African Development Bank, Oxford University Press.

Agbiboa, D. E. (2013). Why Boko Haram Exists: The Relative Deprivation Perspective. African Conflict \& Peacebuilding Review 3(1), 144-157.

Akokpari, J. (2008). Africa's quest for long-term development: Does NEPAD provide the necessary policy framework? African Journal of International Affairs, 11 (1), 32-54.

Alesina, A., Devleeschauwer, A., Easterly, W., Kurlat, S., \& Wacziarg, R. (2003).

Fractionalization. Journal of Economic growth, 8(2), 155-194.

Beehner, L. (2012). The Civil War Paradox. Small Wars Journal.

Collier, P., \& Hoeffler, A. (1998). On economic causes of civil war. Oxford economic papers, 50(4), 563-573.

Collier, P. \& Hoeffler, A. (2000). Greed and Grievance in Civil War. Washington DC: World Bank.

Collier, P. \& Hoeffler, A. (2000). Greed and grievance in civil war. World Bank Policy Research Working Paper 2355. (May). Washington, DC: World Bank.

Collier, P., \& Hoeffler, A. (2004). Greed and grievance in civil war. Oxford economic papers, 56(4), 563-595.

Collier, P., Elliot, L., Hegre, H., Hoeffler, A., Reynal-Querol, M., \& Sambanis, N. (2003). Breaking the conflict trap: civil war and development policy. Washington, DC: World Bank.

Collier, P., \& Sambanis, N. (Eds.). (2005). Understanding civil war: Africa (Vol. 1). World Bank Publications.

Cramer, C. (2005). Angola and the theory of war. In Is violence inevitable in Africa? Theories of Conflict and Approaches to Conflict Prevention by Patrick Chabal, Ulf Engel and Anna-Maria Gentili (eds). Brill Academic Pub, Portland, OR.

Easterly, W., \& Levine, R. (1997). Africa's growth tragedy: policies and ethnic divisions. Quarterly Journal of Economics 111(4), 1203-1250

Fearon, J. \& Laitin, D. (2003). Ethnicity, insurgency, and civil war. American Political Science Review 97(1), 75-90.

Glaeser, E. L., La Porta, R., Lopez-de-Silanes, F., \& Shleifer, A. (2004). Do institutions cause growth? Journal of Economic Growth, 9(3), 271-303. 
Gurr, T. R. (1993). Why minorities rebel: A global analysis of communal mobilization and conflict since 1945. International Political Science Review 14 (2), 161-201.

Hoeffler, A. (2008). Dealing with the consequences of violent conflicts in Africa. Background Paper for the African Development Bank Report 2008

http://users.ox.ac.uk/ ball0144/consequences.pdf

Hoeffler, A., \& Reynal-Querol, M. (2003). Measuring the costs of conflict. Washington, DC: World Bank.

Kimemia, D. (2016). Africa's Social Cleavages and Democratization: Colonial, Post-Colonial, and Contemporary. Rowman and Littlefield, USA.

Lijphart, A. 1999. Patterns of Democracy: Government Forms and Performance in Thirty-six Countries. New Haven and London: Yale University Press.

Montalvo, J. G., \& Reynal-Querol, M. (2005). Ethnic polarization, potential conflict, and civil wars. The American Economic Review, 95(3), 796-816.

Marshall, M., Gurr, T. \& Harff, B. (2012). pitf—state failure problem set: internal wars and failures of government, 1955-2010. Political Instability Task Force, available at: www.systemicpeace.org/inscr/PITFProbSetCodebook2011.pdf

Ndikumana, L., \&Emizet, K. (2005). The economics of civil war: the case of the Democratic Republic of Congo. In understanding civil war: Evidence and analysis. Vol.1. Africa, eds. N. Sambanis and P. Collier, 63-88. Washington, DC: The World Bank.

Reynal-Querol, M. (2002. Ethnicity, political systems, and civil wars. Journal of Conflict Resolution. 46(1), 29-54.

Sambanis, N. (2004). What is a civil war? Conceptual and empirical complexities of an operational definition. Journal of Conflict Resolution 48(6), 814-858.

Sambanis, N. \& Hegre, H. (2006) Sensitivity analysis of the empirical literature on civil war onset. Journal of Conflict Resolution 50(4), 508-535.

Serneels, P., \& Verpoorten, M. (2013). The impact of armed conflict on economic performance evidence from Rwanda. Journal of Conflict Resolution, 0022002713515409.

The Armed Conflict Location \& Event Data Project (ACLED) (2017).

United Nations Development Programme (2014). Human Development Report 2014. Sustaining Human Progress: Reducing Vulnerabilities and Building Resilience. UNDP, New York http://hdr.undp.org/en/content/human-development-index-hdi

Williams, P. (2016). War and Conflict in Africa. Cambridge: Polity. 
Wimmer, A., Cederman, L. E., \& Min, B. (2009). Ethnic politics and armed conflict: A configurational analysis of a new global data set. American Sociological Review, 74(2), 316-337.

Zeleza, P. T. (2008). The causes and costs of war in Africa from liberation struggles to the war on terror. In The roots of African conflicts: The causes and costs by Alfred Nhema and Paul Tiyambe Zeleza (Eds). Addis Ababa and Oxford: OSSREA and James Currey

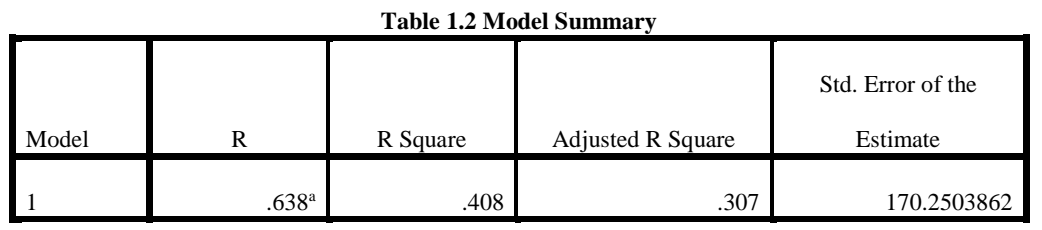

a. Predictors: (Constant), EFAlesinaetal, GDP, POLITYAVER, ReligiousDI, POLEFFECT,

Legitimacy, CPI201213

\begin{tabular}{|c|c|c|c|c|c|c|}
\hline \multirow[b]{2}{*}{ Mode } & & \multicolumn{2}{|c|}{ Unstandardized Coefficients } & \multirow{2}{*}{$\begin{array}{c}\text { Standardized } \\
\text { Coefficients } \\
\text { Beta }\end{array}$} & \multirow[b]{2}{*}{$\mathrm{t}$} & \multirow[b]{2}{*}{ Sig. } \\
\hline & & B & Std. Error & & & \\
\hline \multirow[t]{8}{*}{1} & (Constant) & 488.712 & 217.835 & & 2.244 & .030 \\
\hline & GDP & -24.546 & 10.759 & -.311 & -2.281 & .028 \\
\hline & ReligiousDI & -16.713 & 10.881 & -.193 & -1.536 & .132 \\
\hline & CPI201213 & -7.244 & 3.649 & -.385 & -1.985 & .054 \\
\hline & POLEFFECT & -73.399 & 41.940 & -.295 & -1.750 & .088 \\
\hline & Legitimacy & 49.809 & 13.857 & .637 & 3.594 & .001 \\
\hline & POLITYAVER & 15.508 & 6.728 & .355 & 2.305 & .026 \\
\hline & EFAlesinaetal & -240.065 & 134.758 & -.268 & -1.781 & .082 \\
\hline
\end{tabular}

a. Dependent Variable: Conflicts

Table 1.4

\section{Descriptive Statistics}

\begin{tabular}{lr|r|r|r|r} 
& N & \multicolumn{1}{c|}{ Minimum } & \multicolumn{1}{c}{ Maximum } & \multicolumn{1}{c}{ Mean } & \multicolumn{1}{c}{ Std. Deviation } \\
\hline Conflicts & 49 & 2.2778 & 841.6667 & 138.208617 & 204.4428412 \\
\hline CPI201213 & 49 & 8.0000 & 64.5000 & 31.867347 & 10.8545188 \\
\hline GDP & 49 & -1.46 & 13.14 & 4.6512 & 2.58692 \\
\hline PoliticalRights & 49 & 1.0833 & 7.0000 & 4.827381 & 1.4966446 \\
\hline Civilliberties & 49 & 1.9167 & 7.0000 & 4.549887 & 1.2059594 \\
\hline
\end{tabular}


Kimemia: The Impacts of Political Conflicts in Africa

\begin{tabular}{l|r|r|r|r|r}
\hline StateLegitimacy & 49 & 4.6000 & 9.9429 & 7.698834 & 1.3510686 \\
\hline GroupGrievance & 49 & 3.0857 & 9.9143 & 6.613411 & 1.7434143 \\
\hline ReligiousDI & 49 & .00 & 7.50 & 3.1306 & 2.36601 \\
\hline POLEFFECT & 49 & .0000 & 3.0000 & 1.933760 & .8215865 \\
\hline DEMOCACEVER & 49 & .0000 & 10.0000 & 2.960061 & 2.7389286 \\
\hline AUTOCAVER & 49 & .0000 & 9.1300 & 2.902061 & 2.1761189 \\
\hline POLITYAVER & 49 & -9.1300 & 10.0000 & .071551 & 4.6837622 \\
\hline EconomiEff & 49 & .53 & 4.00 & 2.9785 & 1.13534 \\
\hline Valid N (listwise) & 49 & & & & \\
\hline
\end{tabular}

